\title{
Terrorismo Jihadista e Kamikazes Humanos: Uma Difícil Questão Para a Contemporaneidade
}

\author{
KHOSROKHAVAR, F. Radicalisation. \\ Paris: Éditions de la Maison des sciences de l'homme, 2014. 191 p.
}

Por

\section{Ricardo Colturato Festi ${ }^{1}$}

Os atentados terroristas que atingiram a França em 2015 explicitaram um aspecto extremamente paradigmático da atual constituição das ações do terrorismo jihadista: os executantes não eram unicamente "estrangeiros", provindos de uma nação estigmatizada pela visão eurocêntrica de barbárie; eles eram, em sua maioria, jovens nascidos e criados na "civilização ocidental". Este fato substancial abriu novas fissuras no debate político acerca das causas e das consequências das ações terroristas. As explicações elaboradas tanto pelo governo de François Hollande quanto pela oposição à direita (no caso, Les Republicains de Nicolas Sarkozy e o Front Nacional de Marine Le Pen), reforçando uma visão obscurantista e belicista, aumentaram ainda mais as dificuldades em compreender quais são as bases sociais que levam mais e mais jovens ocidentais a aderirem ao jihadismo terrorista.

Essa é a questão central do livro de Fahad Khosrokhavar, Radicalisation, publicado pela editora da fundação Maison des sciences de l'homme, antes do aumento da influência e das ações do Estado Islâmico. Segundo o autor, o terrorismo jihadista é uma dentre muitas modalidades

1 Doutorando em Sociologia na Universidade Estadual de Campinas (UNICAMP), Brasil. ricardofesti@gmail.com 
de terrorismo evidentes nas últimas décadas e, apesar de seu baixíssimo número de vítimas e de sua reduzida capacidade de atrair novos membros, ele se tornou o centro das preocupações devido a sua capacidade singular de conseguir uma significativa abrangência midiática com as suas ações. Nesse sentido, não importam os fatos, senão a dimensão simbólica que as ações do terrorismo jihadista assume na sociedade: “desse ponto de vista, os terroristas islâmicos 'do interior' são ainda mais inquietantes: eles incarnam não somente uma ameaça, mas também uma traição da identidade europeia” (p. 13).

Khosrokhavar aponta três grandes motivos para o florescimento do radicalismo jihadista. O primeiro estaria no retorno do discurso religioso ao âmbito da política, principalmente aquele que se apresenta sob uma forma violenta - sendo o seu extremo a eliminação física do outro. Esse processo se expressa, também, no desejo do indivíduo pela própria morte, ou seja, pela manifestação de uma "religiosidade mortífera" e no desejo de consagração do mártir. Vale ressaltar que os argumentos do autor permitem compreender o cenário atual de ascensão de diversos grupos fundamentalistas religiosos no campo político em vários países ocidentais de democracia liberal. Para além de seus matizes conjunturais, esses grupos seguem uma mesma lógica: a sacralização do real e a proliferação do irracionalismo.

O segundo motivo para a ascensão do radicalismo jihadista, segundo Khosrokhavar, estaria na desinstitucionalização, processo particular ao mundo ocidental. As profundas derrotas e o enfraquecimento dos partidos de esquerda, principalmente os partidos comunistas, foram o que mais impactou no processo abordado pelo livro. Esses partidos, especialmente na França e na Itália, por décadas cumpriram, devido à enorme força política adquirida depois da Segunda Guerra Mundial, o papel de conferir a numerosos operários e seus filhos uma identidade social e uma dignidade. $\mathrm{O}$ seu declínio "se produziu numa conjuntura onde não havia mais progressão social possível para uma parte importante das classes inferiores, reduzidas à exclusão econômica." (p. 19). 
Por fim, o terceiro motivo estaria associado às políticas neoliberais encaminhadas, a partir do final da década de 1980, tanto nos países ocidentais, atingindo as camadas mais pobres e botando fim ao sonho do welfare state, quanto no Oriente Médio e no mundo árabe por meio de intervenções militares ou governos que proliferaram uma maior precarização da população.

Portanto, a tese do autor reforça uma relação entre o jihadismo terrorista e a exclusão social. Na Europa, esta recaiu sobre as gerações saídas da imigração e que foram reduzidas à marginalidade. No mundo mulçumano, recaiu sobre as camadas sociais modernizadas, ou seja, as classes médias, porta-vozes autoproclamadas de camadas reduzidas à indigência ou à impotência, muitos deles jovens educados que não encontraram emprego e se sentem colocados no ostracismo pelos poderes despóticos e corrompidos de seus países:

A isso se junta o desaparecimento do mundo bipolar, onde a ideologia jogava um rol essencial de um lado como no outro. Agora, o islã assume parte do rol delegado antes às utopias de salvação coletiva, seja em sua versão marxista (a luta de classes colocando fim à injustiça social) ou liberal (o mercado como solução milagrosa a todos os problemas) (p. 20).

Khosrokhavar, além de analisar em seu livro os aspectos objetivos que motivam essas ações, nos conduz ao terreno da subjetividade dos atores, a fim de explorar o fenômeno de sua radicalização no terrorismo jihadista. Para ele, a sociologia deveria se interrogar, em particular, sobre os efeitos a longo prazo da estigmatização, da humilhação, das formas dissimuladas de rejeição e da exclusão pela qual milhões de pessoas são submetidas todos os dias na sociedade. Nesse sentido, a sociologia não deveria apenas se interessar com aquilo que leva alguns indivíduos à radicalização jihadista, mas, sobretudo, com a "significação política e social do fenômeno, o rol dos indivíduos e seus estados mentais e psíquicos estando subordinados ao conjunto da dinâmica social, política e internacional" (p. 17). Interessa ao autor, portanto, menos os aspectos individuais da subjetividade e da psique do "sujeito terrorista" e mais a dinâmica do grupo, como o carisma do líder, a intensidade de apego a ele e aos ideais professados. Nessa perspectiva, o 
autor chama a atenção para o fato de que, depois que o indivíduo passa para a ação, "a radicalização implica ainda uma mobilização simbólica onde as mídias acabam contribuindo para fabricar o status de 'herói negativo' que os radicais (os islâmicos extremistas ou os extremistas laicos como Breivik na Noruega) adotam voluntariamente" (p. 15-16).

Uma das limitações deste livro está na generalização do termo radicalização a toda e qualquer forma de "ideologia extremista" vinculada a uma ação violenta. $O$ conceito serviria para explicar tanto as ações de indivíduos que agem no campo da extrema-direita ou de grupos religiosos fundamentalistas, quanto no da extrema-esquerda. Ele está associado à adesão de Khosrokhavar à democracia liberal, entendida enquanto um valor universal. Assim, "se definimos a cidadania como a integração econômica e social numa sociedade, a radicalização - com sua expressão mais tangível, o terrorismo - é um dos lugares onde se reproduz o mal-estar de uma parte dos cidadãos num mundo desprovido de real cidadania" (p. 185). Nesse sentido, as profundas diferenças entre meios e fins dos diversos grupos políticos que se utilizam da "ação violenta" não importam, gerando um enorme problema analítico. Os primeiros, pautados em "utopias reacionárias" e antimodernas, buscam a conservação ou o retorno a um tempo pretérito. Os segundos, associados a "utopias da salvação coletiva", pautam seus sonhos na emancipação humana. Entre uns e outros há um enorme abismo.

Outra debilidade evidente de Radicalisation, comum a vários autores franceses da geração de Khosrokhavar, está no abandono da análise da conflitividade social desde a perspectiva da luta de classes. O terrorismo jihadista é um objeto espinhoso, de difícil análise e caracterização para os defensores de um marxismo mecanicista e ortodoxo. Porém, se seguirmos o método dialético apontado por Marx, atualizando a teoria a partir de uma análise rigorosa da realidade, a questão do terrorismo pode abrir brechas significativas para a compreensão do mundo contemporâneo. E, nesse sentido, independentemente das limitações que possamos encontrar neste livro resenhado, ele é um ótimo ponto de partida para todos que queiram encabeçar essa reflexão. 